\title{
Pre-registration and Global Supply Chains: Compliance with KKDIK
}

\author{
Yaprak Yuzak Kucukvar*
}

\section{Introduction}

Turkey implemented the EU REACH Regulation ${ }^{1}$ within the framework of the harmonization of European Union acquis by introducing Turkish REACHlike regulation known as Kimyasalların Kaydı, Değerlendirilmesi, İzni ve Kısıtlanmasına Hakkında Yönetmelik (KKDIK). ${ }^{2}$ It was published on 23 June 2017 and replaced CICR, the former chemicals inventory regulation. ${ }^{3}$ The Ministry of Environment and Urbanisation (MoEU) is responsible from the implementation and enforcement of KKDIK. The regulation affects all manufacturers in Turkey and importers placing substances, mixtures and articles on the Turkish market. KKDIK does not only effect Turkish manufacturers but also impacts manufacturers located outside of Turkey with the result that nonTurkish manufacturers put the compliance burden on their Turkish subsidiaries or go through the work intensive process of appointing an 'Only Representative'. The heavy workload means that companies must soon start preparing their KKDIK registrations.

\section{Pre-Registration Phase for KKDIK}

According to Article 7 of KKDIK, any manufacturer or importer of a substance, either on its own or in a mixture in quantities of one ton or more per year must submit a registration to the MoEU through the Chemicals Registration System (KKS) which is accessible from the website of the MoEU. In order to register a substance, all potential registrants must submit information on the identity of the substance and its role in their supply chain to the MoEU through KKS by the 31 December 2020 (Provisional Article 1-(1)). This process is similar to the pre-registration process performed in REACH-IT in the EU and is referred to as submitting a pre-SIEF or joining pre-SIEF in KKDIK guidance documents. The term pre-registration is mostly used in this report to facilitate better understanding.

There is a general misconception that companies have a window of three years for pre-registering substances after which SIEF communications will begin, followed by registration preparations in 2021. How- ever, it is clearly stated in the 'Guidance on Registration'4 that each potential manufacturer or importer of a substance manufactured or imported over 1 ton per year must submit a pre-SIEF to continue manufacturing or importing. It is also mentioned in the same document that this process allows potential registrants to contact the related SIEF for data sharing, highlighting that pre-SIEFs must be submitted to the Ministry by 31 December 2020.

As a result of this misconception, some manufacturers erroneously believe that they can pre-register by the end of 2020. Accordingly there is not urgency in regard to the timing of pre-registering a substance under the KKDIK and it must be understood that companies placing chemicals on the market without pre-registering are not compliant with the current regulation in Turkey.

The aim of pre-SIEFs is to facilitate data sharing for registration purposes and to prevent duplication of work, as well as enabling potential registrants to reach an agreement on the classification and labelling (C\&L) of the substance when there is a discrepancy on between co-registrants. The ECHA 'Guidance on Data Sharing' has also been translated into Turkish and adaptations to Turkish laws reflect this. The main regulatory principles in data sharing are identical with those of the EU. The list of translated and adapted Guidance documents published on the MoEU website are shown in Table 1.

DOI: 10.21552/icrl/2019/2/8

* Dr Yaprak Yuzak Kucukvar is the Manager of REACH Global Services Group Turkey Office. For Correspondence: <yaprak@reach-gs.eu>.

1 Regulation (EC) No 1907/2006 of the European Parliament and of the Council of 18 December 2006 concerning the Registration, Authorisation and Restriction of Chemicals(REACH), establishing a European Chemicals Agency, amending Directive 1999/45/EC and repealing Council Regulation (EEC) No 793/93 and Commission Regulation (EC). No $1488 / 94$ as well as Council Directive 76/769/EEC and Commission Directives 91/155/EEC, 93/67/EEC, 93/105/EC and 2000/21/EC [2006] O] L 396/1.

2 Kimyasalların Kaydı, Değerlendirilmesi, İzni ve Kısıtlamas Hakkında Yönetmelik [2017] Turkish Official Gazette No 30105 (Mükerrer)

3 Kimyasalların Envanteri ve Kontrolü Hakkında Yönetmelik [2008] Turkish Official Gazette No 27092 (Mükerrer.)

4 MoEU Guidance on Registration (2017) <http://webdosya.csb.gov .tr/db/cygm/icerikler/kayit-rehberi10052018-1-20180730163839 docx $>$ accessed 17 June 2019. 
Table 1 - Guidance Documents Published by the MoEU in Turkish

\begin{tabular}{|l|}
$\begin{array}{l}\text { Guidance on registration - Guidance on Implementation of } \\
\text { KKDIK }\end{array}$ \\
\hline $\begin{array}{l}\text { Guidance on information requirements and chemical safe- } \\
\text { ty assessment }\end{array}$ \\
\hline Guidance for Annex V \\
\hline Guidance on requirements for substances in articles
\end{tabular}

Guidance for identification and naming of substances under KKDIK and CLP

Guidance on data-sharing

Guidance for Downstream Users

Guidance on intermediates

Guidance on waste and recovered substances

Guidance for monomers and polymers

Guidance on Scientific Research and Development (SR\&D) and Product and Process Orientated Research and Development (PPORD)

Guidance in a nutshell on Compilation of Safety Data Sheets

Factsheet on Toll Manufacturers under the KKDIK Regulation

Factsheet - Information on Chemicals - What you can find in ECHA's Databases

Factsheet - Guidance and Tools for Downstream Users

KKS online system User Manual

Meanwhile, the term 'late pre-registration' has not been introduced by the MoEU yet and according to the Guidance on registration, the Inquiry Process seems to be the procedure to follow for companies

5 Türk Ticaret Kanunu[2011] Turkish Official Gazette No 27846 Numbered 6102. placing chemicals on the Turkish market for the first time after 31 December 2023; the deadline for registration. However, it is foreseen that a procedure for companies who miss the pre-registration phase will be developed by the MoEU closer to the deadline for pre-registrations.

\section{The Importance of Global Supply Chain Perspective and Creating an Inventory}

Creating an inventory is the first step to compliance but it is not as straightforward as one might suspect. It may take months and involves a decision process where manufacturers or importers need to assess whether there are any exemptions applicable to their products or if the right EC names, EC numbers and CAS numbers are used to define the substances. Proceeding with a wrong substance identity will be a waste of time, effort and money in addition to losing access to the market as a result of non-compliance.

Global companies placing chemicals on the Turkish market have various manufacturing sites around the world. As more regulatory measures are introduced around the world, companies will need to ensure that they are compliant in every region from which they import and export.

Therefore it is crucial to create an inventory for each legal entity and ensuring that substances comply with KKDIK (pre-)registration obligation and track volumes associated with each downstream user in Turkey. Although the tonnage band of a substance is not requested during the pre-registration process, it is important to keep track of volumes in order to determine the correct tonnage band for the registration dossier. This information is also important as the decision to become a lead registrant and activity level of the company at the SIEF and consortium must be decided.

Turkish Commercial Code, ${ }^{5}$ like legal systems around the world, distinguishes between different private legal entities ie - incorporated (Inc), limited (Ltd), collective, commandite, cooperatives and associations. In addition, subsidiaries and sister companies are also classified as legal entities. However, each legal entity is independent, so they are solely responsible for their debt and obligations as well as managing the risks associated with the chemicals placed 
on the market and meeting the regulatory obligations.

A legal entity may have many different roles depending on its activities (eg manufacturer or importer) even with respect to the same substance in the supply chain. The roles and responsibilities must be determined correctly. Hence, in principle, each legal entity must submit its own registration for each individual substance unless exempt from the obligation to register under KKDIK. In the event of an OR appointment, a separate OR contract must be signed by each legal entity. On the other hand, if one legal entity has two or more production plants which are not separate legal entities, then only one registration and OR contract covering the different sites needs to be submitted by the legal entity. ${ }^{4}$

It is strongly advised that below influencing factors are considered when creating the inventory of substances.

\section{Centralisation of Information Flow and REACH Experience}

Companies that have experienced complying with EU REACH and have been actively involved in EU consortia, may prefer to centralise the KKDIK compliance process within the company group. Different legal entities of the same company group acting without harmonisation through separate methods of compliance is not a preferred compliance path and may cause future conflicts. Flow of information within the company group plays an important role for smooth trouble-free operation for compliance. The importance of REACH experience gained over the years is an advantage for a company in respect to KKDIK. The lessons learned from previous mistakes during REACH compliance will be of particular benefit.

\section{Influence of Indirect Imports on Volumes}

KKDIK does not distinguish between direct and indirect imports. Therefore, volume tracking and coverage for compliance starts is of importance in Turkey. Indirect import is also an important issue in the EU and not easy to track or to inspect. The MoEU and other Ministries including the Ministry of Trade,
Turkish chemicals sector associations, consultancy companies and all stakeholders have started creating awareness amongst manufacturers and importers that the 'No Data - No Market' principle applies. This will increase the demand for KKDIK compliant chemicals among importers and may trigger more inspections in Turkey.

\section{Toll Manufacturing - Not to be Ignored}

The guidance documents of the MoEU only lists the obligations of toll manufactures based in Turkey. ${ }^{6}$ Toll manufacturers located outside of Turkey are not mentioned but it is certainly an aspect to be considered. Global companies that have toll manufactured chemicals at different locations around world must decide whether to include these substances in the substance inventory lists or not. If non-Turkish toll manufacturer has an interest in the Turkish market and already ship the toll manufactured chemicals directly to Turkey, then the registration obligation may reside with the toll manufacturer and the volumes of the company may be covered under their pre-registrations. However, this may not be the case or toll manufacturer may not prefer to cover that specific volume under the (pre) registration and the two parties should discuss this supply chain compliance issue.

\section{Correct Decision on the Identity of the Substance}

ECHA's Factsheet 'Information on Chemicals" is one of the first important documents the MoEU chose to translate, adopt and publish. It emphasises the importance of the ECHA database and urges manufacturers to check their substance identity through the ECHA registered substances database directing companies to four key databases. It is apparent that the MoEU supports manufacturers and importers to register the substance (EC \& CAS number) registered

6 MoEU Factsheet on Toll Manufacturer under KKDIK Regulation see <http://webdosya.csb.gov.tr/db/cygm/icerikler/kkdik-ve-fason --malat-b-lg--notu-20180731110118.pdf> accessed 17 June 2019.

7 MoEU Factsheet on Information on Chemicals see $<$ http:// webdosya.csb.gov.tr/db/cygm/icerikler/k-myasallara--l-sk-n-b-lg -ler-20180731110100.DOCX> accessed 17 June 2019. 
with ECHA, provided that the company can prove compatible substance identity with the one specified in the EU for that particular substance. This is also supported by the MoEU Guidance for Identification and Naming of Substances in the Scope of KKDIK and SEA, ${ }^{8}$ which is based on the equivalent ECHA Guidance.

\section{Solutions for Non-Turkish Companies}

Global companies may choose to manage compliance through their subsidiary offices in Turkey. This is preferred when all imports into Turkey flow through the Turkish office of the global company only and no indirect imports are anticipated. The biggest issue in regard to this option arises when the human resources of the company in Turkey are not sufficient and not qualified to adequately complete the task.

The other option for global companies is to appoint an Only Representative in Turkey according to Article 9 of KKDIK. Article 9 of KKDIK is identical with Article 8 of EU REACH. The duties of an OR are explained in more detail in the KKDIK Guidance on registration. ${ }^{4}$ This option makes tracking of the direct and indirect imports of the substances more manageable as an Only Representative is a third party legally responsible from the substance and duties including but not limited to keeping track of volumes and performing all the processes for compliance in accordance with KKDIK. Actors in the supply chain may disclose information for coverage purposes to the OR under confidentiality, without commercial concerns.

Companies may also appoint their local importer to perform the (pre-)registrations and manage compliance processes so that they can place compliant chemicals on the market. This option was utilised by many non-EU companies while complying with

8 MoEU Guidance for Identification and Naming of Substances in the Scope of KKDIK and SEA <http://webdosya.csb.gov.tr/db/ cygm/icerikler/madde-tanimlama-ve-isimlendirme-rehberi-tr-1 -20180731110134.docx> accessed 17 June 2019.

9 Maddelerin ve Karışımların Sınıflandırılması, Etiketlenmesi ve Ambalajlanması Hakında Yönetmelik [2013] Turkish Official Gazette No 28848 (Mükerrer)

10 Regulation (EC) No 1272/2008 on the Classification, Labelling and Packaging of Substances and Mixtures amending and repealing Directive 67/548/EEC and 1999/45/EC, and amending Regulation EC No 1907/2006 (CLP Regulation) [2008] OJ L 353/1.
REACH. Unfortunately the process was problematic for some. Even when an importer is the only importer for a global company shipping to Turkey, there is no guarantee that the business relationship between two parties will last forever and in the event of a conflict, the global company may be left without any (pre) registrations and must start the compliance process from scratch.

\section{Inseparable Duo - KKDIK and SEA}

The Turkish By-Law on the Classification, Labelling and Packaging of Substances and Mixtures ${ }^{9}$ (SEA) entered into force on 11 December 2013 and is an implementation of EU CLP Regulation. ${ }^{10}$ It must be noted that KKDIK and SEA cannot be separated when it comes to compliance. Both regulations are managed through the same online IT system; KKS and to be able to submit SEA notifications, companies must join pre-SIEF. Hence, substances with no obligation to register may be present in the pre-SIEF as a result of KKS functioning. It is the responsibility of the company to oversee both regulations and determine obligations through KKS.

\section{Conclusion}

The MoEU has shown a continuous effort to harmonise Turkish chemicals regulations with the EU since 2008 but there is still a long transitional period until all chemicals in the Turkish market are completely registered and in line with the EU REACH Regulation.

In particular the pre-registration phase of KKDIK forces all manufacturers and importers to create their inventory for Turkey very carefully. This process can take months for companies with a global presence, if Turkey is an important market for different segments of the company group. Some aspects to be considered while shaping the inventory are the correct identification of the substance, indirect imports into Turkey, toll manufacturing and the centralisation of the compliance process within the company group.

There are different options for compliance and each company should choose the most appropriate methodology and practice. The company's method of compliance must be shaped in such a way that it 
should suit specific company needs. All business units of a company group must have a smooth transition period for compliance where direct and indi- rect exportations to Turkey are guaranteed to be covered with ease and volume tracking becomes a routine practice. 